\title{
Economic Cooperation in the Greater Mekong Sub-Region
}

\author{
Binh Hai Le ${ }^{1}$, Dang Quyen Nguyen², Kieu Trang Vu², Hiep Ngoc Luu ${ }^{3+}$, \\ and Farhad Taghizadeh-Hesary ${ }^{4}$ \\ ${ }^{1}$ Diplomatic Academy of Vietnam, Vietnam \\ ${ }^{2}$ Centre for Applied Economics and Business Research, Vietnam \\ ${ }^{3}$ University of St Andrews, UK \\ ${ }^{4}$ Waseda University, Japan
}

\begin{abstract}
This paper investigates the impact of regional economic cooperation between Vietnam and its partners during the 2000-2015 period, focusing on the Greater Mekong Sub-region (GMS). Overall, the GMS represents a significant portion of Vietnam's trade portfolio. China is the dominant trading partner in the GMS, exhibiting strong influence over Vietnam's trade, especially its imports. However, using the gravity model of trade, we find that Vietnam has not benefited from GMS cooperation, as exemplified by its significant trade deficit, particularly with China. We further find that human capital enhancement and financial development are key factors to facilitate Vietnam's trade, and mitigate its trade deficit with other GMS member countries. To this end, this study provides some important policy implications for the Vietnamese government as well as policymakers in other countries, when trading with larger partners in the context of regional economic cooperation.
\end{abstract}

Keywords: Regional Economic Cooperation, Greater Mekong Sub-region, Vietnam, Trade, Gravity Model JEL Classifications: F13, F15, C23, O53

Received 24 April 2019, Revised 19 June 2019, Accepted 8 July 2019

\section{Introduction}

It is confidently assumed that regional economic cooperation can facilitate trade and beget economic gains to member states by deterring violent conflicts and misconceptions (Hoekman

\footnotetext{
+Corresponding Author: Hiep Ngoc Luu

Researcher, University of St Andrews, The Gateway, North Haugh, St Andrews, UK, and Centre for Applied Economics and Business Research, 70 Nam Dong, Hanoi, Vietnam, Email: nhl3@st-andrews.ac.uk

Co-Author: Binh Hai Le

Deputy Director, Diplomatic Academy of Vietnam, 69 Chua Lang, Hanoi, Vietnam, Email: haibinhvn@gmail.com Co-Author: Dang Quyen Nguyen

Researcher, Centre for Applied Economics and Business Research, 70 Nam Dong, Hanoi, Vietnam,

Email: dangquyen.dav@gmail.com

Co-Author: Kieu Trang Vu

Researcher, Centre for Applied Economics and Business Research, 70 Nam Dong, Hanoi, Vietnam,

Email: vukieutrang1502@gmail.com

Co-Author: Farhad Taghizadeh-Hesary

Associate Professor of Economics, Waseda University, 1 Chome-104 Totsukamachi, Shinjuku City, Tokyo, Japan; Email: Farhad@aoni.waseda.jp
} 
et al., 2002); lowering trade barriers (Mwasha, 2008); facilitating bilateral investments (Park \& Park, 2009); increasing productivity (Salvatore, 2006); and fostering specialization (Baldwin $\&$ Venables, 2004). However, many acts of cooperation do not pan out as expected. Yang and Gupta (2008); and Todaro and Smith (2015) found that regional cooperation can be ineffective due to the low complementary nature of resources among participants, high level of trade barriers, and limited transport infrastructure.

Yet, although a number of studies have investigated the nexus between cooperation and economic outcomes, the empirical evidence on whether regional cooperation facilitates or impedes the economic outcomes of participating countries has not been settled. China's recent Belt and Road Initiative (BRI) has attracted the attention of governments, academic researchers, and the business community worldwide (Du, 2018; Zhai, 2018), reviving the debate over the gain/loss of regional economic cooperation. The BRI's objective is to strengthen collaboration and stimulate development across sixty countries spanning Asia, Africa, and Europe.

As a pivotal part of the BRI, the Mekong sub-region is the nucleus in China's political and economic policies, given its unique geopolitical location, continuous border with China, and a high level of sub-regional cooperation (Vannarith, 2018a). The China-led Lancang-Mekong Cooperation (LMC) was officially launched 2005. It engages in much broader cooperation, ranging from political and security issues, sustainable economic development, and social-cultural and people-to-people exchanges. Arguably, the LMC is a major channel through which China could leverage its political and economic influence in the Mekong region and ultimately facilitate its ambitious BRI (Du, 2018; Yu, 2018).

Nevertheless, researchers remain skeptical about the potential benefits of Mekong cooperation. Krongkaew (2004) found that cooperation in the Mekong sub-region can be unproductive and may impose significant disadvantages on member countries due to discrepancies in development, and conflicts between and political instability within member countries. While there have been fifteen cooperations formed in the GMS, the economic impact on members is ambiguous, and the extant literature falls short of offering adequate empirical investigation.

This paper empirically investigates whether regional economic cooperation brings trade gains to member countries, with the main focus on the GMS. Vietnam provides a uniquely interesting case, not only due to the dearth of previous studies, but also because of its specific geographical position bordering China, and near worldwide supply chains. Since Vietnam gained WTO accession in 2007, its trade policy has been oriented toward facilitating globalism and multilateralism as a part of the central plans for achieving sustainable economic growth. However, given escalating complexity in negotiating multilateral trade deals, Vietnam has prioritized bilateralism and regionalism assuming each is more conducive and complementary to trade liberalization (TPR, 2013). In addition, although Vietnam has participated in much regional cooperation, policy makers and academic scholars doubt the 'so-called' social-economic benefits (Pham, 1999; 
Schmidt, 2004), calling for more in-depth investigation of the cooperation-trade nexus, as well as the potential positive channels and/or circumstances that could affect trade.

The remainder of this paper is structured as follows. Section II overviews the literature on regional economic cooperation and trade. Section III discusses current economic GMS cooperation, as well as Vietnam's participation. Section IV discusses the data and model. Section $\mathrm{V}$ reports the empirical results. Section VI discusses potential channels affecting trade between Vietnam and the other GMS countries. Section VII concludes and offers policy recommendations.

\section{Regional Economic Cooperation and Trade - A Review of the Literature}

The literature documents the positive relationship between regional economic cooperation and trade gains (Aitken, 1973; Khazeh and Clark, 1990; Fernandez and Portes, 1998; Iyoha, 2005). Aitken (1973) empirically weighed the impact of the European Economic Community and the European Free Trade Association on member trade and finds an increasing trade growth. Fernandez and Portes (1998) investigated the impact of regional trade agreements on their partners, finding that in addition to the traditional gains of trade, a number of nontraditional benefits including credibility, signaling, bargaining power, insurance, and coordination could be achieved when joining a regional trade agreement. Iyoha (2005) discussed how regional economic integration affects intra-African trade, agreeing with Fernandez and Portes (1998) that economic cooperation positively affects trade, primarily by increasing market size, competition, and investment. Yang and Martinez-Zarzoso (2014) found a positive relationship between regional cooperation and trade between China and the ASEAN Free Trade Area, mostly due to the removal of tariff barriers between intra-bloc and extra-bloc countries.

Nevertheless, regional economic cooperation may not always benefit members. Yang and Gupta (2008) found that African regional economic cooperation does not significantly promote bilateral trade, possibly because of high external trade barriers and low resource complementarity among members. Cooperation can also bring negative effects if trade diversion outweighs trade creation (Todaro \& Smith, 2015).

The literature on the GMS is sparse. Yu (2003), Krongkaew (2004), and Poncet (2006) are among the few papers focusing on the Mekong area investigated the GMS, but were not able to definitively assess the effects of Mekong cooperation on its members. Specifically, Yu (2003) investigated the benefits and drawbacks of constructing a regional power-grid market in the GMS, arguing that institutional barriers, national interest, and differing levels of energy development are major obstacles that challenge the potential success of this common energy market. Thus, GMS countries should accelerate regional cooperation with a flexible approach to energy policy and energy reforms. Krongkaew (2004) asserts a more nationalist attitude 
that smaller countries are more likely to suffer a patron-client relationship, in which the larger countries accrue all benefits through size and market power. Subsequently, Poncet (2006) analyzed the evolution of Yunnan economic integration with the GMS, finding that bilateral trade between Yunnan and the GMS has decreased over the 1988-1999 period.

Despite little investigation of the impact of Mekong cooperation on Vietnam's trade, researchers have posited that the long-standing issues of a lack of experience in international business and overlapping bureaucratic administrative systems can obscure any benefits from cooperation (Schmidt, 2004). Pham (1999) even posited that regional economic cooperation could negatively impact Vietnam's economy because domestic firms lack competitiveness, and become vulnerable when Vietnam economically cooperates with more advanced nations. In addition, the removal of tariffs may increase non-tariff barriers that Vietnamese firms usually fail to satisfy, such as the Sanitary and Phytosanitary Measures, and the Technical Barriers to Trade. This makes it difficult for Vietnam's goods to be exported (OECD, 2005), resulting in accelerated trade deficits as imports exceed exports, hampering the country's economy. To this end, while the Vietnamese government has provided support for GMS cooperation, whether or not the country can expect trade gains is still an open empirical question that warrants investigation

\section{Regional Cooperation in the GMS}

\section{A. The mekong basin and regional cooperation}

The Mekong is the twelfth largest river in the world and the longest in Southeast Asia. Its genesis lies in the Tibetan highlands, and flows through the Chinese province of Yunnan; Myanmar, Laos, Thailand, and Cambodia, and finally Vietnam. The GMS, an area of 2.3 million square kilometers with a population of 242.8 million, is an important geopolitical region.

The GMS has to date employed up to 15 mechanisms, including both intra-bloc and extra-bloc cooperation. With the former, cooperation in the Mekong Basin began in 1957 when the Mekong Committee was launched at the initiative of the United Nation Economic Commission for Asia and the Far East (ECAFE). Accordingly, the Committee's principal objectives were to solve the rising problems of poverty and political instability along the lower river basin and to promote peace and prosperity through an effective joint exploitation of the river's resources.

However, Mekong cooperation was interrupted by subsequent wars and conflicts. The process re-gained momentum in 1992 when six riparian countries of the Mekong River, assisted by the Asian Development Bank (ADB) formalized the sub-regional cooperation to be known as the Greater Mekong Sub-region. Since then, the ADB has been the main sponsor of most cooperative initiatives. The GMS program has been directed toward the facilitation of sustainable 
economic growth and improving living standards in the Mekong region through factor input specialization and greatly expanded trade and investment. Since 1992, the ADB has loaned US\$ 280 million to priority projects and disbursed US\$ 7.6 million for technical assistance to study suitable programs and projects, and for project consultation activities.

In addition, the UN and the World Bank, and other sponsor countries such as Japan, France, Australia, and the US provide support broadening the context of GMS cooperation. For example, the Japanese government has recently promised JPY 750 billion in the form of Official Development Assistance to the GMS, in order to promote infrastructure and sustainable development; and the United States has also pledged to assist the development of the region by sending its experts and scholars.

\section{B. Vietnam's participation in regional and economic cooperation in the greater mekong sub-region}

The Mekong river plays a pivotal role in Vietnam's economic activities: Twenty percent of Vietnam lies within the Mekong Basin, which produces half the country's agricultural products, including eighty percent of rice, ninety percent of rice exports, and roughly fifty percent of seafood exports. Thus, Vietnam has contributed to Mekong cooperation, mostly through promoting trade, facilitating collaboration initiatives, and providing financial assistance to neighboring countries.

The Vietnamese government has simplified customs for trading goods and people crossing. It grants travel rights to vehicles of the GMS members, and has invested in large infrastructure projects, including a number of expressways and harbors, to link Vietnamese provinces with other GMS cities in order to facilitate cooperation and trade. Ultimately, this has accelerated trade volume between Vietnam and GMS members.

Figure 1 illustrates the evolution of Vietnam's trade with the GMS members. While Vietnam's exports to the GMS members started off quite low in 2000, 2001, and 2003, they modestly yet steadily increased, reaching US\$ 8.0 billion in 2009 and US\$ 19.0 billion in 2012 . Nevertheless, the growth rate of exports has recently decelerated, achieving only US\$23.0 billion in 2015 . 
Figure 1. Vietnam's trade with GMS members

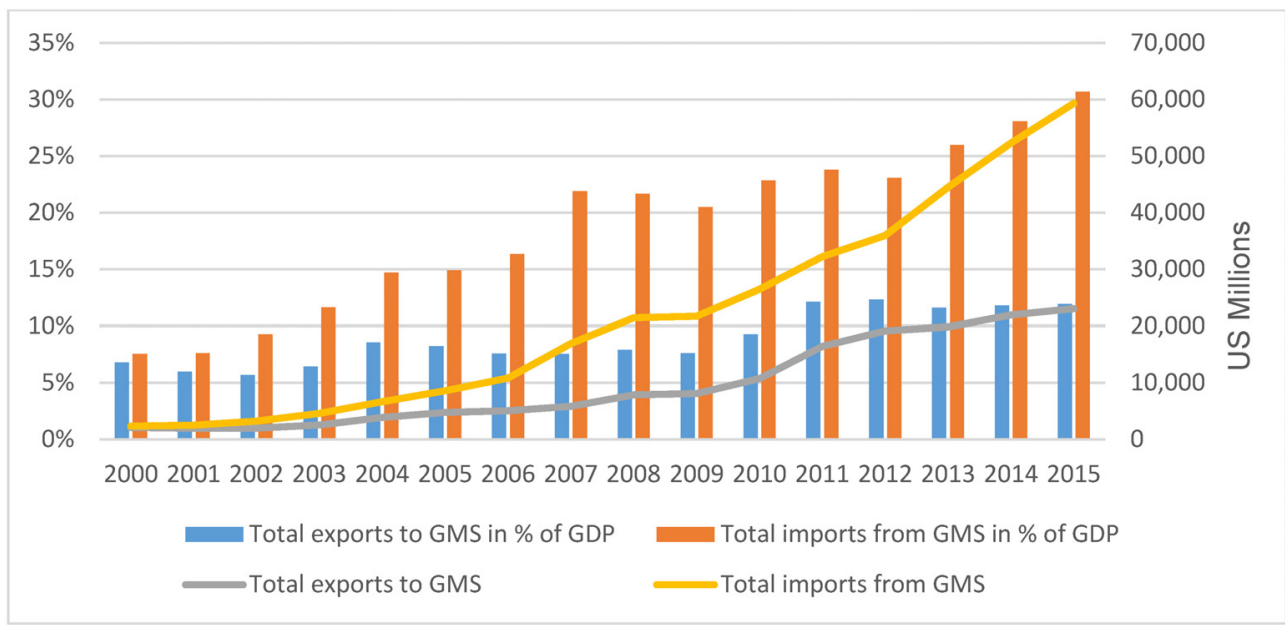

(Source) Author's calculation using data from the World Integrated Trade Solution (WITS).

Figure 1 demonstrates that, overall, Vietnam's imports are significantly greater than its exports, indicating a substantial trade deficit. Despite starting at a low point in the first three years of the 21 st century, import values subsequently accelerated, peaking in 2015 US\$ 59.30 billion, accounting for over 30 percent of Vietnam's Gross Domestic Product (GDP). This upsurge produced a trade deficit US\$ 36.26 billion in 2015.

Table 1 demonstrates the relative importance of GMS countries to Vietnam's imports. Overall, import values with the GMS increased over 25-fold in fifteen years, US\$ 59.30 billion in 2015. Vietnam's imports from China increased the most, from just US\$ 1.401 billion in 2000 to US\$ 49.44 billion in 2015, followed by Thailand with US\$ 8.27 billion in 2015. Accordingly, the GMS's share of Vietnam's total imports increased from 15.02 percent in 2000 to 35.83 percent in 2015, with China also taking the biggest share. During the period 2008-2015, despite a minor setback in the case of Myanmar, overall, GMS's share of the increase in Vietnam's imports reaches 44.48 percent, with China the main player.

Table 2 illustrates the relative importance of GMS countries to Vietnam's exports. In 2015, Vietnam exports to GMS countries soared to US\$23.04 billion, a ten-fold increase since 2000. However, the proportion of total exports sent to the GMS remained at around 14 percent. Except for Cambodia and Myanmar, the proportion of Vietnam's exports to GMS countries in 2015 declined compared to the year 2000. Still, China was Vietnam's biggest export destination in the GMS with US\$ 16.57 billion in goods and services 2015, accounting for 10.2 percent of Vietnam's total exports.

To obtain a more cohesive picture of the Mekong economic cooperation during the period 2000-2015, Table 3 displays Vietnam's trade balance with other GMS countries As indicated, 
Vietnam has had a large and increasing trade deficit with the GMS. While Vietnam's trade balance with the rest of the world has been positive since 2010, it has been persistently negative with the GMS countries. Notably, Vietnam's trade deficit with China is the most significant at US\$ 32 billion in 2015, more than six-fold that with Thailand, Vietnam's second largest trading partner. On the other hand, Vietnam has trade surpluses with Cambodia and Myanmar. Intriguingly, despite constant trade deficits with the GMS countries, Vietnam has experienced stable and rising surpluses with the rest of the world due to Vietnam's enhancement in national competitiveness and international trade opportunities.

Table 1. Relative importance of GMS countries to vietnam's imports

\begin{tabular}{|c|c|c|c|c|c|}
\hline & \multicolumn{2}{|c|}{$\begin{array}{c}\text { Import value } \\
\text { (US\$ Thousands) }\end{array}$} & \multicolumn{2}{|c|}{ Share of total imports (\%) } & \multirow{2}{*}{$\begin{array}{c}\text { Share of increase in } \\
\text { imports (\%) } \\
2008-2015\end{array}$} \\
\hline & 2000 & 2015 & 2000 & 2015 & \\
\hline GMS & $2,358,621$ & $59,299,323$ & 15.02 & 35.83 & 44.48 \\
\hline Cambodia & 37,298 & 945,967 & 0.2 & 0.6 & 0.9 \\
\hline China & $1,401,137$ & $49,441,123$ & 8.9 & 29.8 & 39.3 \\
\hline Lao PDR & 105,730 & 586,487 & 0.7 & 0.4 & 0.4 \\
\hline Myanmar & 3,593 & 56,178 & 0.02 & 0.03 & -0.02 \\
\hline Thailand & 810,863 & $8,269,567$ & 5.2 & 5.0 & 3.9 \\
\hline
\end{tabular}

(Source) Author's calculation using data from the World Integrated Trade Solution (WITS).

Table 2. Relative importance of GMS countries to vietnam's exports

\begin{tabular}{|c|c|c|c|c|c|}
\hline & \multicolumn{2}{|c|}{$\begin{array}{c}\text { Export value } \\
\text { (US\$ Thousands) }\end{array}$} & \multicolumn{2}{|c|}{ Share of total exports (\%) } & \multirow{2}{*}{$\begin{array}{c}\text { Share of increase in } \\
\text { exports }(\%)\end{array}$} \\
\hline & 2000 & 2015 & 2000 & 2015 & \\
\hline GMS & $2,124,998$ & $23,039,607$ & 14.53 & 14 & 15.3 \\
\hline Cambodia & 141,620 & $2,395,221$ & 0.9 & 1.4 & 0.9 \\
\hline China & $1,536,391$ & $16,567,686$ & 10.6 & 10.2 & 11.8 \\
\hline Lao PDR & 69,009 & 523,311 & 0.5 & 0.3 & 0.4 \\
\hline Myanmar & 5,666 & 375,724 & 0.03 & 0.2 & 0.3 \\
\hline Thailand & 372,312 & $31,77,666$ & 2.5 & 1.9 & 1.9 \\
\hline
\end{tabular}

(Source) Author's calculation using data from the World Integrated Trade Solution (WITS). 
Table 3. Trade balance of vietnam with GMS countries 2000-2015 (US\$ Thousands)

\begin{tabular}{lrrrrrrrr}
\hline & 2000 & 2005 & 2010 & 2011 & 2012 & 2013 & 2014 & 2015 \\
\hline GMS & $-233,623$ & $-3,831,134$ & $-15,737,998$ & $-15,784,755$ & $-16,781,301$ & $-24,631,612$ & $-30,344,736$ & $-36,259,715$ \\
Cambodia & 104,322 & 395,421 & $1,287,199$ & $2,089,430$ & $2,387,386$ & $2,430,348$ & $2,062,031$ & $1,449,254$ \\
China & 135,254 & $-2,653,285$ & $-12,460,693$ & $-13,253,068$ & $-16,198,990$ & $-23,708,783$ & $-28,719,251$ & $-32,873,437$ \\
Lao PDR & $-36,721$ & $-28,337$ & $-91,761$ & $-173,444$ & $-18,314$ & $-245,538$ & $-318,117$ & $-63,177$ \\
Myanmar & 2,073 & $-33,801$ & $-53,301$ & $-2,343$ & 8,337 & 106,232 & 210,361 & 319,546 \\
Thailand & $-438,551$ & $-1,511,132$ & $-4,419,440$ & $-4,445,329$ & $-2,959,720$ & $-3,213,870$ & $-3,579,759$ & $-5,091,901$ \\
Rest of the word & $-920,162$ & $-482,853$ & $3,136,110$ & $5,940,575$ & $17,530,041$ & $24,631,934$ & $32,722,827$ & $32,500,599$ \\
\hline
\end{tabular}

\section{Data and Econometric Model Specifications}

\section{A. Data and sample overview}

The data used for our analysis were extracted, processed, and merged from a number of sources. Specifically, import and export volumes were retrieved from the World Integrated Trade Solution (WITS) database for the period 2000-2015. Data on geographical distance between Vietnam and its partners were obtained from the GeoDist Database provided by the Centre d'Études Prospectives et d'Informations Internationales (CEPII). These distances are between the geographic coordinates of the largest cities in each country. Data on the history of conflicts between Vietnam and its partners were collected from the Uppsala Conflict Data Program of Uppsala University, 2017. Data on members of WTO/GATT were taken from the WTO's homepage. Data on regional trade agreements (RTAs) were collected from Vietnam's Ministry of Planning and Investment. Data for other macroeconomic variables, unless otherwise noted, were retrieved from the World Development Indicators, provided by the World Bank.

Our sample size comprises 188 countries with whom Vietnam has a trading relationship. Table 4 defines the main variables, and Table 5 reports the summary statistics. 
Table 4. Variable definitions and sources

\begin{tabular}{|c|c|c|}
\hline Variables & Definition & Source \\
\hline Ln (Export) & $\begin{array}{l}\text { Natural logarithm of the total value of } \\
\text { Vietnam's exports }\end{array}$ & $\begin{array}{l}\text { The World Integrated Trade } \\
\text { Solution (WITS) }\end{array}$ \\
\hline Ln (Import) & $\begin{array}{l}\text { Natural logarithm of the total value of } \\
\text { Vietnam's imports }\end{array}$ & $\begin{array}{l}\text { The World Integrated Trade } \\
\text { Solution (WITS) }\end{array}$ \\
\hline Ln (Total income) & $\begin{array}{l}\text { Natural logarithm of Vietnam's GDP } \\
\text { multiplied by a partner's GDP }\end{array}$ & $\begin{array}{l}\text { Author's calculation using data from } \\
\text { the World Development Indicators }\end{array}$ \\
\hline Ln (Regional per capita income) & $\begin{array}{l}\text { Natural logarithm of Vietnam's per capita } \\
\text { income }\end{array}$ & $\begin{array}{l}\text { The World Development Indicators } \\
\text { database }\end{array}$ \\
\hline Ln (Destination per capita income) & $\begin{array}{l}\text { Natural logarithm of partner countries' per } \\
\text { capita income }\end{array}$ & $\begin{array}{l}\text { The World Development Indicators } \\
\text { database }\end{array}$ \\
\hline $\operatorname{Ln}(D I F G D P)$ & $\begin{array}{l}\text { Natural logarithm of the absolute value of the } \\
\text { difference between Vietnam's GDP and the } \\
\text { partner's GDP }\end{array}$ & $\begin{array}{l}\text { Author's calculation using data from } \\
\text { the World Integrated Trade Solution } \\
\text { (WITS) }\end{array}$ \\
\hline Ln (Distance) & $\begin{array}{l}\text { Natural logarithm of the weighted distance } \\
\text { between Vietnam's largest city and that of the } \\
\text { partner country }\end{array}$ & $\begin{array}{l}\text { The GeoDist Database provided by } \\
\text { the CEPII }\end{array}$ \\
\hline Trade Openness & $\begin{array}{l}\text { The share of total exports and imports to real } \\
\text { GDP }\end{array}$ & $\begin{array}{l}\text { Author's calculation using data from } \\
\text { the World Development Indicators }\end{array}$ \\
\hline Conflict & $\begin{array}{l}\text { Dummy variable, coded } 1 \text { if the partner has a } \\
\text { history of conflict with Vietnam, and } 0 \text { otherwise. }\end{array}$ & $\begin{array}{l}\text { Uppsala Conflict Data Program of } \\
\text { Uppsala University }\end{array}$ \\
\hline Contiguous border & $\begin{array}{l}\text { Dummy variable, coded } 1 \text { if Vietnam and the } \\
\text { partner have an inland border, and } 0 \text { otherwise. }\end{array}$ & $\begin{array}{l}\text { The GeoDist Database provided by } \\
\text { the CEPII }\end{array}$ \\
\hline Trade Agreement & $\begin{array}{l}\text { Dummy variable, coded } 1 \text { if Vietnam and the } \\
\text { partner have a Trade Agreement, and } 0 \text { otherwise. }\end{array}$ & $\begin{array}{l}\text { Vietnam's Ministry of Planning and } \\
\text { Investment }\end{array}$ \\
\hline
\end{tabular}

(Source) Authors' compilation

Table 5. Summary statistics

\begin{tabular}{lrrrrrrrr}
\hline \multicolumn{1}{c}{ Variable } & Obs. & \multicolumn{1}{c}{ Mean } & St. Dev. & \multicolumn{1}{c}{ Min } & \multicolumn{1}{c}{ p.25 } & Median & p.75 & Max \\
\hline Ln (Export) & 2452 & 16.476 & 3.051 & 6.297 & 14.408 & 16.588 & 18.514 & 24.234 \\
Ln (Import) & 2219 & 16.198 & 3.331 & 0.693 & 14.224 & 16.382 & 18.525 & 24.624 \\
Ln (Total income) & 2,397 & 48.901 & 2.628 & 40.599 & 47.021 & 48.870 & 50.718 & 56.515 \\
Ln (Regional per capita income) & 2,452 & 6.834 & 0.586 & 5.962 & 6.234 & 6.923 & 7.388 & 7.633 \\
Ln (Destination per capita income) & 2,397 & 8.285 & 1.593 & 4.713 & 6.987 & 8.301 & 9.562 & 11.543 \\
Ln (DIFGDP) & 2,408 & 25.227 & 1.307 & 16.786 & 24.362 & 25.210 & 25.789 & 30.517 \\
Ln (Distance) & 2,452 & 8.997 & 0.665 & 6.280 & 8.823 & 9.105 & 9.394 & 9.868 \\
Trade Openness & 2,452 & 1.434 & 0.205 & 1.114 & 1.275 & 1.453 & 1.597 & 1.788 \\
\hline
\end{tabular}

(Source) Authors' compilation

\section{B. The gravity model of trade}

Based on the literature (Kahouli \& Maktouf, 2015; Narayan \& Nguyen, 2016), we utilized the traditional gravity model of trade to evaluate Vietnam's trade with partners. We start with 
the earliest model proposed by Tinbergen (1962):

$$
\text { Trade }_{i j}=G * \frac{G D P_{i} * G D P_{j}}{\text { Distance }_{i j}}
$$

Equation (1) explains the volume of bilateral trade flows ( Trade $_{i j}$ ) between country $i$ and $j$ (where $i$ is Vietnam and $j$ is its trading partner country), depending on: the GDP of country $i\left(G D P_{i}\right)$; the GDP of country $j\left(G D P_{j}\right)$; and the geographical distance between the two countries ( Distance $_{i j}$ ). Additionally, the gravity model consists of a gravitational constant, $G$, which is independent of both $i$ and $j$, and captures country-independent effects.

Based on (1), we estimate the following equation:

$$
\ln (\text { Trade })_{i j}=\alpha_{0}+\alpha_{1} \ln \left(G D P_{i} * G D P_{j}\right)+\alpha_{2} \ln (\text { Distance })_{i j}+\mu_{i j}
$$

Equation (2) is the simplest form of the gravity model. However, this specification has been criticized for being incomplete since it disregards multilateral resistance factors to trade such as trade agreements, common language, common colonial base, remoteness, and adjacency (Anderson and Wincoop, 2003). Thus, we follow the literature by incorporating variables capturing economic, demographic, geographic conditions, and trade-creating policies, in order to model bilateral trade flow more accurately between Vietnam and its partners. Specifically, based on the literature (Kastner, 2007; Cipollina \& Salvatici, 2010; Kahouli \& Maktouf, 2015; Narayan \& Nguyen, 2016) we include Vietnam's GDP per capita; the GDP per capita of the partner countries; the difference in GDP between Vietnam and its trading partners; trade openness; conflict; contiguous borders; and trade agreements. It is worth noting that other studies (Oh \& Selmier II, 2008; Kahouli \& Maktouf, 2015; Lewer \& Van den Berg, 2008) use colonial links and common language; however as far as we are concerned, there are no common languages or colonial links between Vietnam and its trading partners.

As our main focus, we include a dummy variable indicating the GMS, which allows us to explicitly evaluate the trade flow of Vietnam with other GMS members compared with other regions. Thus, the model to estimate Vietnam's trade is specified as:

$$
\begin{aligned}
& \ln (\text { Trade })_{i j}=\alpha_{0}+\alpha_{1} \ln \left(G D P_{i} * G D P_{j}\right)+\alpha_{2} \ln (\text { Regional per capita income })_{i} \\
& +\alpha_{3} \ln (\text { Destination per capita income })_{j}+\alpha_{4} \ln (\text { DIFGDP })_{i j} \\
& +\alpha_{5} \ln \left(\text { Distance }_{i j}+\alpha_{6} \text { Trade Openness }{ }_{i}+\alpha_{7} \text { Conflict }_{i j}\right. \\
& +\alpha_{8} \text { Contiguous Border }{ }_{i j}+\alpha_{9} \text { Trade Agreement }{ }_{i j}+\alpha_{10} G M S+\mu_{i j}
\end{aligned}
$$

Where Trade $_{i j}$ is the trade flow between countries $i$ and $j$. Here, we separately consider 
trade in terms of the total volume of Vietnam's exports to partner countries, and the total volume of Vietnam's imports from partner countries. $G D P_{i}$ and $G D P_{j}$ are the GDP of countries

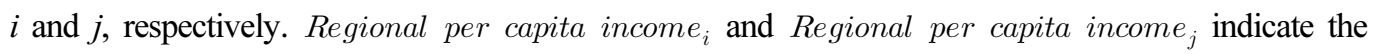
GDP per capital of country $i$ and country $j$, respectively. DIFGDP $P_{i j}$ is the absolute value of the difference in GDP between country $i$ and country $j$. Distance ${ }_{i j}$ is the geographical distance between two countries $i$ and $j$. Trade Openness reflects the level of openness in terms of trade, measured by the sum of total exports and imports divided by total GDP. Conflict $_{i j}$ notes an historical conflict between countries $i$ and $j$, equal to 1 if conflict has existed, and 0 otherwise. Contiguous Border $r_{i j}$, a dummy variable equal to 1 if countries $i$ and $j$ share a common border, and 0 otherwise. Trade Agreement ${ }_{i j}$ describes the Free Trade Agreement (FTA) between countries $i$ and $j$. A dummy variable, it equals 1 if both countries $i$ and $j$ have signed the FTA, and 0 otherwise. GMS is a univariate variable indicating the Greater Mekong Sub-region. $\mu_{i j}$ denotes the residual term.

\section{Empirical Results - Baseline Regressions}

The gravity model has traditionally been estimated cross-sectionally. This approach has been criticized for obtaining unreliable results since it might exclude or mis-measure trading pair-specific variables (Baldwin, 2006) and it might be unable to capture the relevant relationships between variables over time. To mitigate this problem, we estimate our gravity model with the utilization of time-series cross-sectional (panel) data.

The two common methods used in panel data analysis are fixed effects and random-effects. The former is used to surmount the problem of the traditional pooled cross-section method unable to cope with bilateral (exporter and/or importer) heterogeneity (Cheng \& Wall, 2005; Anderson \& Wincoop, 2003). However, this approach does not allow for the inclusion of key exporter and importer invariant factors, and subsequently excludes important economically relevant trade variables (Prehn et al., 2016). As our main focus is on time-constant variables, such as the Great Mekong Sub-region Cooperation, dummies indicating GMS member countries, and the geographical distance from Vietnam to its trading partners, the random-effects is more appropriate. Therefore, we follow the literature (Kavallari et al., 2008; Keum, 2010; Prehn et al., 2016) and employ a panel random-effects approach to evaluate the trade flows between Vietnam and other countries.

\section{A. Exports}

Table 6 displays the results obtained with the random-effects approach to analyzing the 
determinants of Vietnamese exports. The dependent variable is the natural logarithm of export volume. Column 1 provides the results for Vietnam's export flows, estimated from the baseline regression, using a GMS dummy to evaluate the trade flow between Vietnam and the GMS members. To attain a more detailed analysis, we separately considered the trade volume between Vietnam and each GMS member by incorporating dummy variables indicating China, Laos, Cambodia, Myanmar, and Thailand into the specification. Columns 2-6 present the specification including only one of the GMS countries at a time.

Overall, the estimated coefficients of the explanatory variables Ln (Total income) and Ln (Distance) are consistent with the expected signs. The exports from Vietnam increase with the GDP of Vietnam and its trading partners $(p<0.01)$ and decrease with distance. In addition, the GDP per capita of the destination and regional countries are negatively associated with export volume because the estimated coefficients on Ln (Regional per capita income) and Ln (Destination per capita income) are negative and statistically significant at $p<0.05$ and $p<0.01$, respectively. We further find that a larger difference in economic size (DIFGDP) between countries is positively related to export flows since the estimated coefficient on $\operatorname{Ln}$ (DIFGDP) is positive and statistically significant at $p<0.1$. Moreover, the relationships between trade openness and contiguous borders, as well as trade agreements and Vietnam's exports, are positive and significant.

Regarding the regional dummies, since the estimated coefficient on GMS is negative and statistically significant (Column 1), it indicates that the level of goods and services exported from Vietnam to GMS member countries is below the normal level. Specifically, the export flow from Vietnam to GMS members is 62.4 percent [exp (-0.977) $-1=-0.624$ ] lower than the normal level predicted by the countries' GDP, the distance between them, and multilateral resistance factors.

Results from Columns 2-6 indicate that the level of exporting to China and Myanmar is significantly lower than the normal level, whereas exports to Cambodia are significantly higher. It is worth noting that China is a main trading partner of Vietnam, with the largest proportion of total exports compared to other countries within the GMS. However, the estimated coefficient on the China dummy indicates that the volume of exports to China is 87.2 percent $[\exp (-2.057)=-0.872]$ lower than the normal level. 
Table 6. Determinants of vietnam's exports

\begin{tabular}{|c|c|c|c|c|c|c|}
\hline & \multicolumn{6}{|c|}{ Exports } \\
\hline & (1) & (2) & (3) & (4) & (5) & (6) \\
\hline \multirow[t]{2}{*}{ Ln (Total income) } & $0.935 * * *$ & $0.937 * * *$ & $0.933 * * *$ & $0.934 * * *$ & $0.934 * * *$ & $0.933 * * *$ \\
\hline & $(0.047)$ & $(0.047)$ & $(0.047)$ & $(0.047)$ & $(0.047)$ & $(0.047)$ \\
\hline \multirow[t]{2}{*}{ Ln (Regional per capita income) } & $-0.980 * *$ & $-0.986 * *$ & $-0.982 * *$ & $-0.984 * *$ & $-0.976^{* *}$ & $-0.982 * *$ \\
\hline & $(0.492)$ & $(0.492)$ & $(0.492)$ & $(0.492)$ & $(0.492)$ & $(0.492)$ \\
\hline \multirow[t]{2}{*}{ Ln (Destination per capita income) } & $-0.242 * * *$ & $-0.240 * * *$ & $-0.236 * * *$ & $-0.236^{* * *}$ & $-0.243 * * *$ & $-0.236^{* * *}$ \\
\hline & $(0.076)$ & $(0.076)$ & $(0.076)$ & $(0.075)$ & $(0.076)$ & $(0.075)$ \\
\hline \multirow[t]{2}{*}{$\operatorname{Ln}(D I F G D P)$} & $0.113^{*}$ & $0.112 *$ & $0.112^{*}$ & $0.113^{*}$ & $0.112 *$ & $0.112 *$ \\
\hline & $(0.060)$ & $(0.060)$ & $(0.060)$ & $(0.060)$ & $(0.060)$ & $(0.060)$ \\
\hline \multirow[t]{2}{*}{ Ln (Distance) } & -0.104 & -0.102 & -0.089 & -0.089 & -0.093 & -0.089 \\
\hline & $(0.215)$ & $(0.214)$ & $(0.214)$ & $(0.214)$ & $(0.214)$ & $(0.216)$ \\
\hline \multirow[t]{2}{*}{ Trade Openness } & $3.210 * * *$ & $3.214 * * *$ & $3.216^{* * *}$ & $3.217 * * *$ & $3.207 * * *$ & $3.216^{* * *}$ \\
\hline & (1.197) & (1.197) & (1.197) & (1.197) & (1.197) & (1.197) \\
\hline \multirow[t]{2}{*}{ Conflict } & 0.319 & $0.720 * *$ & 0.239 & 0.442 & 0.320 & 0.251 \\
\hline & $(0.441)$ & $(0.302)$ & $(0.479)$ & $(0.366)$ & $(0.441)$ & $(0.468)$ \\
\hline \multirow[t]{2}{*}{ Contiguous border } & $2.379 * * *$ & $2.224 * * *$ & $1.665^{* *}$ & $1.038^{*}$ & $1.430 * *$ & $1.628 * *$ \\
\hline & $(0.726)$ & $(0.636)$ & $(0.825)$ & $(0.547)$ & $(0.608)$ & $(0.662)$ \\
\hline \multirow[t]{2}{*}{ Trade Agreement } & $2.415 * * *$ & $2.017 * * *$ & $2.188 * * *$ & $2.126^{* * *}$ & $2.404 * * *$ & $2.173 * * *$ \\
\hline & $(0.629)$ & $(0.611)$ & $(0.597)$ & $(0.585)$ & $(0.593)$ & $(0.616)$ \\
\hline \multirow[t]{2}{*}{$G M S$} & $-0.977^{*}$ & & & & & \\
\hline & $(0.758)$ & & & & & \\
\hline \multirow[t]{2}{*}{ China } & & $-2.057 * * *$ & & & & \\
\hline & & $(0.643)$ & & & & \\
\hline \multirow[t]{2}{*}{ Laos } & & & -0.128 & & & \\
\hline & & & $(0.768)$ & & & \\
\hline \multirow[t]{2}{*}{ Cambodia } & & & & $1.669 * * *$ & & \\
\hline & & & & $(0.455)$ & & \\
\hline \multirow[t]{2}{*}{ Myanmar } & & & & & $-1.724 * * *$ & \\
\hline & & & & & $(0.450)$ & \\
\hline \multirow[t]{2}{*}{ Thailand } & & & & & & 0.080 \\
\hline & & & & & & $(0.508)$ \\
\hline R-squared & 0.6464 & 0.6463 & 0.6463 & 0.6463 & 0.6464 & 0.6463 \\
\hline Observations & 2,397 & 2,397 & 2,397 & 2,397 & 2,397 & 2,397 \\
\hline
\end{tabular}

(Note) (i) Constant terms are not reported for brevity

(ii) Robust standard errors are in parentheses

(iii) $*, * *, * * *$ indicate the significance level at $10 \%, 5 \%$, and $1 \%$, respectively

\section{B. Imports}

Table 7 displays the results obtained via the random-effects approach to analyze the determinants 
of Vietnamese imports from GMS members. The dependent variable is the natural logarithm of the import volume.

The regression in column 1 displays results with the incorporation of the GMS regional

Table 7. Determinants of vietnam's imports

\begin{tabular}{|c|c|c|c|c|c|c|}
\hline & \multicolumn{6}{|c|}{ Imports } \\
\hline & (1) & (2) & (3) & (4) & (5) & (6) \\
\hline \multirow[t]{2}{*}{ Ln (Total income) } & $0.833 * * *$ & $0.832 * * *$ & $0.834 * * *$ & $0.833 * * *$ & $0.834 * * *$ & $0.831 * * *$ \\
\hline & $(0.067)$ & $(0.068)$ & $(0.068)$ & $(0.068)$ & $(0.068)$ & $(0.067)$ \\
\hline \multirow[t]{2}{*}{ Ln (Regional per capita income) } & 0.964 & 0.966 & 0.964 & 0.965 & 0.969 & 0.967 \\
\hline & $(0.591)$ & $(0.591)$ & $(0.591)$ & $(0.591)$ & $(0.592)$ & $(0.592)$ \\
\hline \multirow[t]{2}{*}{ Ln (Destination per capita income) } & -0.019 & -0.019 & -0.021 & -0.020 & -0.025 & -0.017 \\
\hline & $(0.099)$ & $(0.100)$ & $(0.100)$ & $(0.100)$ & $(0.100)$ & $(0.099)$ \\
\hline \multirow[t]{2}{*}{ Ln $(D I F G D P)$} & $0.246 * * *$ & $0.247 * * *$ & $0.246 * * *$ & $0.246^{* * *}$ & $0.246^{* * *}$ & $0.246 * * *$ \\
\hline & $(0.081)$ & $(0.081)$ & $(0.081)$ & $(0.081)$ & $(0.081)$ & $(0.081)$ \\
\hline \multirow[t]{2}{*}{ Ln (Distance) } & -0.347 & -0.346 & -0.352 & -0.350 & -0.353 & -0.333 \\
\hline & $(0.271)$ & $(0.270)$ & $(0.269)$ & $(0.269)$ & $(0.269)$ & $(0.271)$ \\
\hline \multirow[t]{2}{*}{ Trade Openness } & -1.891 & -1.892 & -1.893 & -1.892 & -1.899 & -1.892 \\
\hline & (1.578) & (1.578) & $(1.578)$ & $(1.578)$ & $(1.579)$ & $(1.578)$ \\
\hline \multirow[t]{2}{*}{ Conflict } & 0.227 & 0.110 & 0.278 & 0.153 & 0.281 & 0.202 \\
\hline & $(0.527)$ & $(0.493)$ & $(0.510)$ & $(0.495)$ & $(0.529)$ & $(0.507)$ \\
\hline \multirow[t]{2}{*}{ Contiguous border } & $1.497^{*}$ & $1.476 * *$ & $1.523 * * *$ & $1.906 * * *$ & $1.527 * *$ & $1.795 * * *$ \\
\hline & $(0.794)$ & $(0.700)$ & $(0.557)$ & $(0.479)$ & $(0.614)$ & $(0.597)$ \\
\hline \multirow[t]{2}{*}{ Trade Agreement } & $2.418 * * *$ & $2.508 * * *$ & $2.447 * * *$ & $2.488 * * *$ & $2.595^{* * *}$ & $2.316^{* * *}$ \\
\hline & $(0.842)$ & $(0.798)$ & $(0.762)$ & $(0.755)$ & $(0.797)$ & $(0.776)$ \\
\hline \multirow[t]{2}{*}{ GMS } & 0.187 & & & & & \\
\hline & $(1.030)$ & & & & & \\
\hline \multirow[t]{2}{*}{ China } & & $0.567^{*}$ & & & & \\
\hline & & $(0.794)$ & & & & \\
\hline \multirow[t]{2}{*}{ Laos } & & & 0.333 & & & \\
\hline & & & $(0.409)$ & & & \\
\hline \multirow[t]{2}{*}{ Cambodia } & & & & $-0.756^{* * *}$ & & \\
\hline & & & & $(0.271)$ & & \\
\hline \multirow[t]{2}{*}{ Myanmar } & & & & & -1.030 & \\
\hline & & & & & $(0.638)$ & \\
\hline \multirow[t]{2}{*}{ Thailand } & & & & & & $1.343 * *$ \\
\hline & & & & & & $(0.640)$ \\
\hline R-squared & 0.4873 & 0.4873 & 0.4874 & 0.4874 & 0.4874 & 0.4874 \\
\hline Observations & 2,185 & 2,185 & 2,185 & 2,185 & 2,185 & 2,185 \\
\hline
\end{tabular}

(Note) (i) Constant terms are not reported for brevity

(ii) Robust standard errors are in parentheses

(iii) $*, * *, * * *$ indicate the significance level at $10 \%, 5 \%$, and $1 \%$, respectively 
dummy to examine the import flow into Vietnam from GMS members. To attain a more detailed result, we replicated the procedure in the Exports sub-section and separately incorporated dummy variables indicating China, Laos, Cambodia, Myanmar, and Thailand into the specification. Columns 2-6 present the specification including only one of the GMS countries at a time.

Overall, the signs of the coefficients of the two basic explanatory variables Ln (Total income) and $\operatorname{Ln}$ (Distance) comport with the classical results of the gravity model. We further find that the large difference in GDP between Vietnam and its trading partners resulted in an increase in Vietnam's import volume. In addition, the effects of a contiguous border, and trade agreement on Vietnam's imports are positive and statistically significant.

The estimated coefficients of the GMS regional dummy, although positive, are not statistically significant. And the estimated coefficients of China and Thailand are positive and significant, indicating that Vietnam's imports from China and Thailand are higher than the normal level. These results attest that China and Thailand account for a large proportion of Vietnam's total imports, and the import volume from these countries has increased significantly from 2000 to 2015. On the other hand, we find that Vietnam's imports from Cambodia are less than the normal level, as the estimated coefficient on Cambodia is negative and statistically significant.

Taken together, our results comport with Krongkaew (2004) who argued that when entering into cooperation with GMS members, smaller countries like Vietnam may not benefit from trade gains since the larger trading partners (e.g., Thailand and China) can take advantage of the size and market power to accrue all the gains from trade.

\section{Channels That Can Facilitate Trade}

In this section, we investigate channels that help to facilitate Vietnam's trade with its partners, especially with the GMS, principally human capital enhancement and financial development.

\section{A. Human capital}

A large number of studies consider human capital as a critical factor in determining the growth of trade flows (Contractor \& Mudambi, 2008; Levin \& Raut, 1997; Gomez-Mejia, 1988). Levin and Raut (1997) found significant complementarities between export performance and human capital. In addition, Contractor and Mudambi (2008) examined the human capital investment and export performance of the top 25 service-outsourcing countries, finding that human capital significantly affects the exports of both services and goods. Based on the literature, we expect human capital enhancement to promote Vietnam's imports and exports.

To test this hypothesis, we incorporate into the baseline regression (3) a variable capturing 
the human capital level in Vietnam, as well as its interaction term with the GMS dummy. Specifically, based on the literature we include the natural logarithm of the total number of university and college students in Vietnam to proxy for human capital. Next, we follow the procedure conducted in earlier sections of this study and examine whether human capital enhancement can yield a significant impact on the bilateral trade of Vietnam with each GMS member. We first estimate our specification for the export volumes. Then, we replicate this exercise for imports. Table 8 displays the combined results.

Overall, they reinforce our prior findings. The signs and magnitudes of key variables are largely unchanged even with different interaction terms incorporated into the model. The interaction terms themselves also provide some important insights. The estimated coefficients on GMS*Human capital are all positive and statistically significant for both exports and imports, indicating that the volume of exports and imports with countries in the GMS increases when human capital is enhanced. The interaction terms of Human capital with other GMS country dummies are always positive and significant, evidencing that human capital is an effective channel for promoting the trade flows of Vietnam.

\section{B. Trade openness and financial development}

Beck (2002) and Shahbaz and Rahman (2014) have asserted that development of the financial sector could facilitate trade flows. According to Rajan and Zingales (1998), and Svaleryd and Vlachos (2005), the development of the financial sector allows enterprises to access external funds more conveniently, by increasing the amount of accessible funds and reducing the cost of external financing. As a result, it could reduce the problem of liquidity shortage, and ultimately promote trade.

Another literature strand evidences the positive impact of trade openness on trading activities, especially exports (Arslan \& Wijnbergen, 1993; Ahmed, 2000; Krueger, 1997), partly because trade liberalization diminishes anti-export bias and helps exports become more competitive in an international market. Hence, in this sub-section, we attempt to conduct another robustness check, examining whether trade openness and financial development affect Vietnam's trade. We follow Lee and Chang (2009) and use the ratio of liquid liabilities to GDP to proxy for financial development (Financial development), and incorporate it into Eq. (3), along with its interaction term with Trade openness. Table 9 displays the regression results.

While the interaction term between Trade openness and Financial development is positive and significant in all export models, the estimated coefficients of Trade openness*Financial development are insignificant in all import models. This indicates that while trade openness can facilitate Vietnam's exports of goods and services as the financial system becomes more developed, it has no significant impact on the country's import levels. As a result, financial 


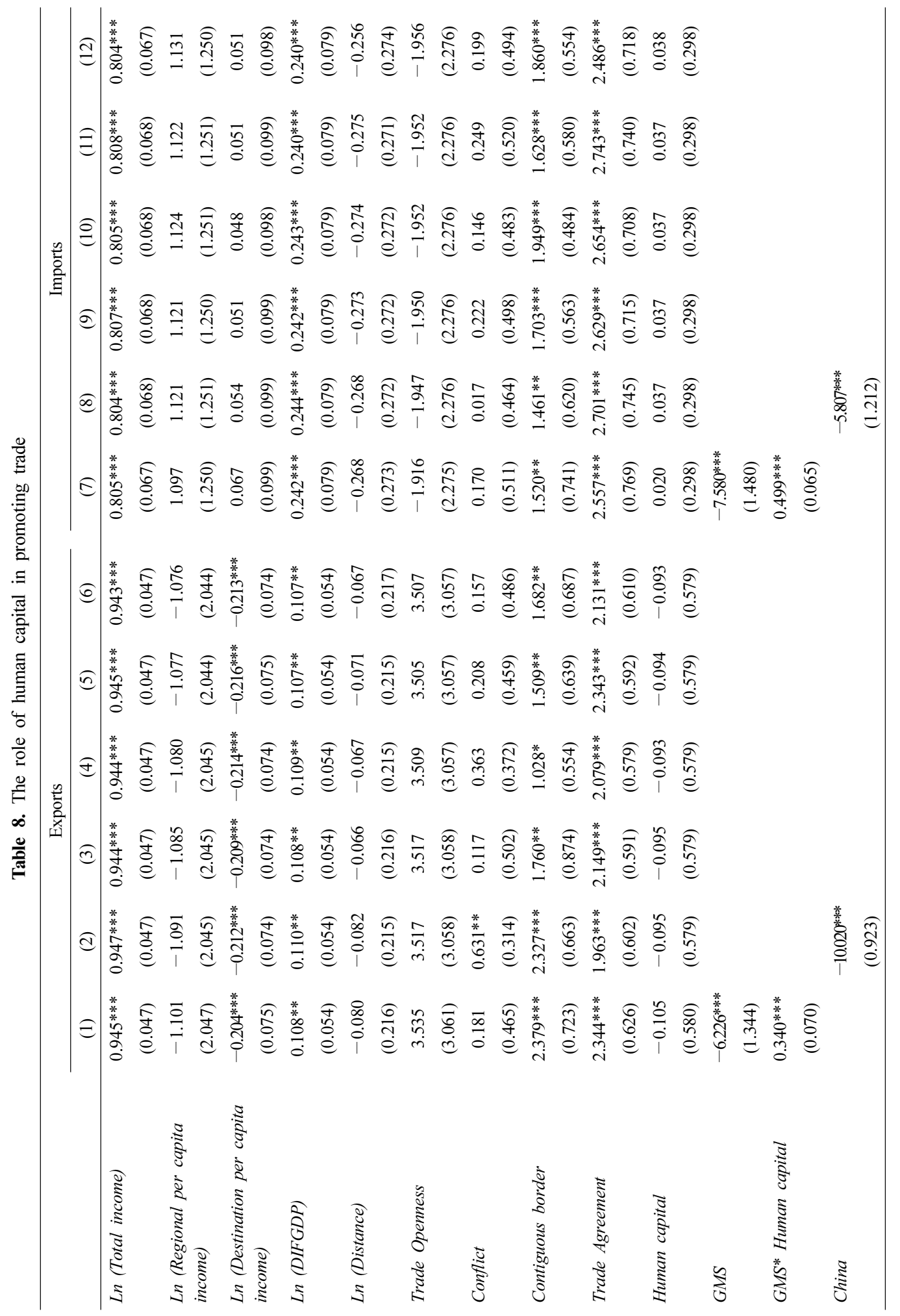




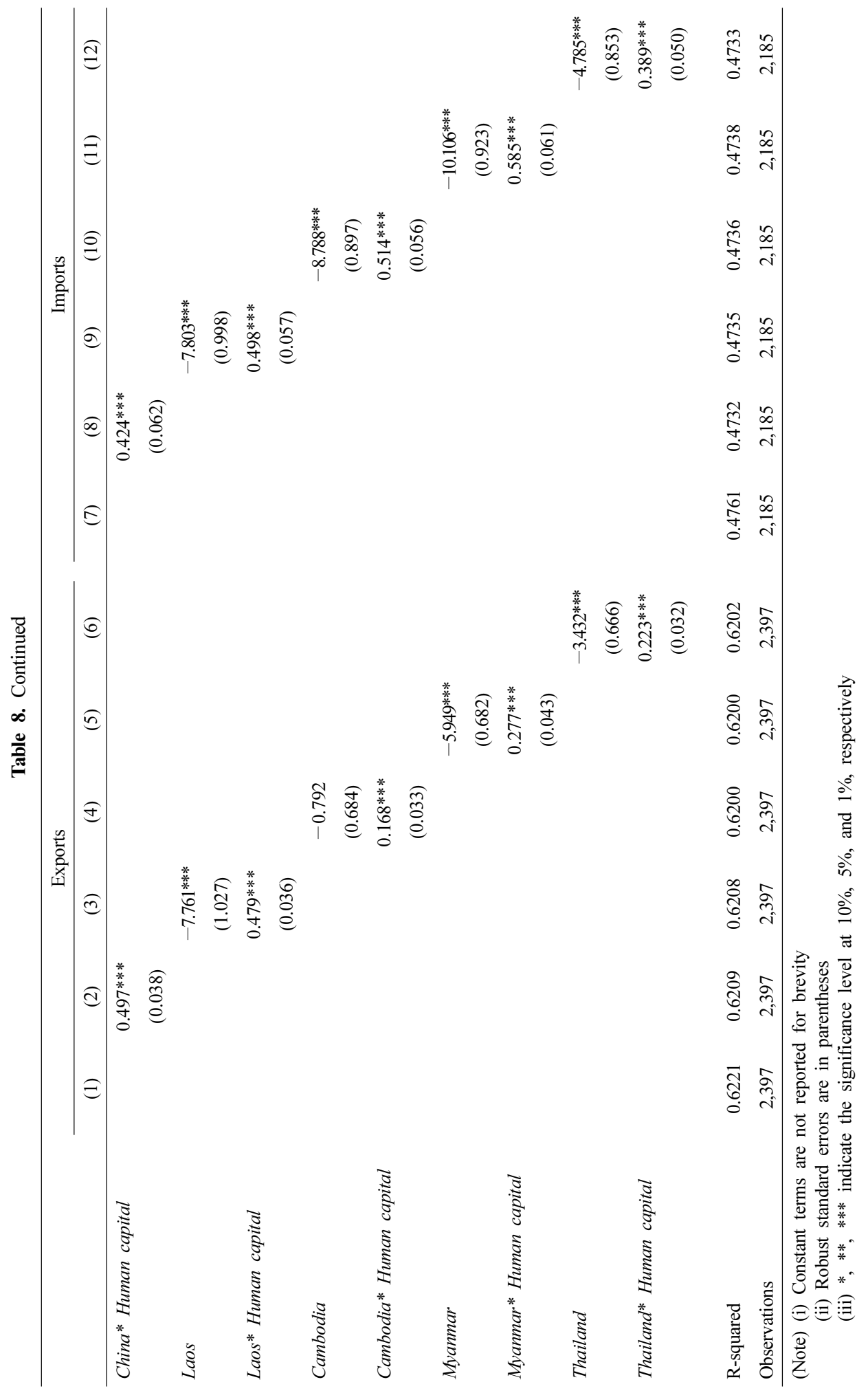




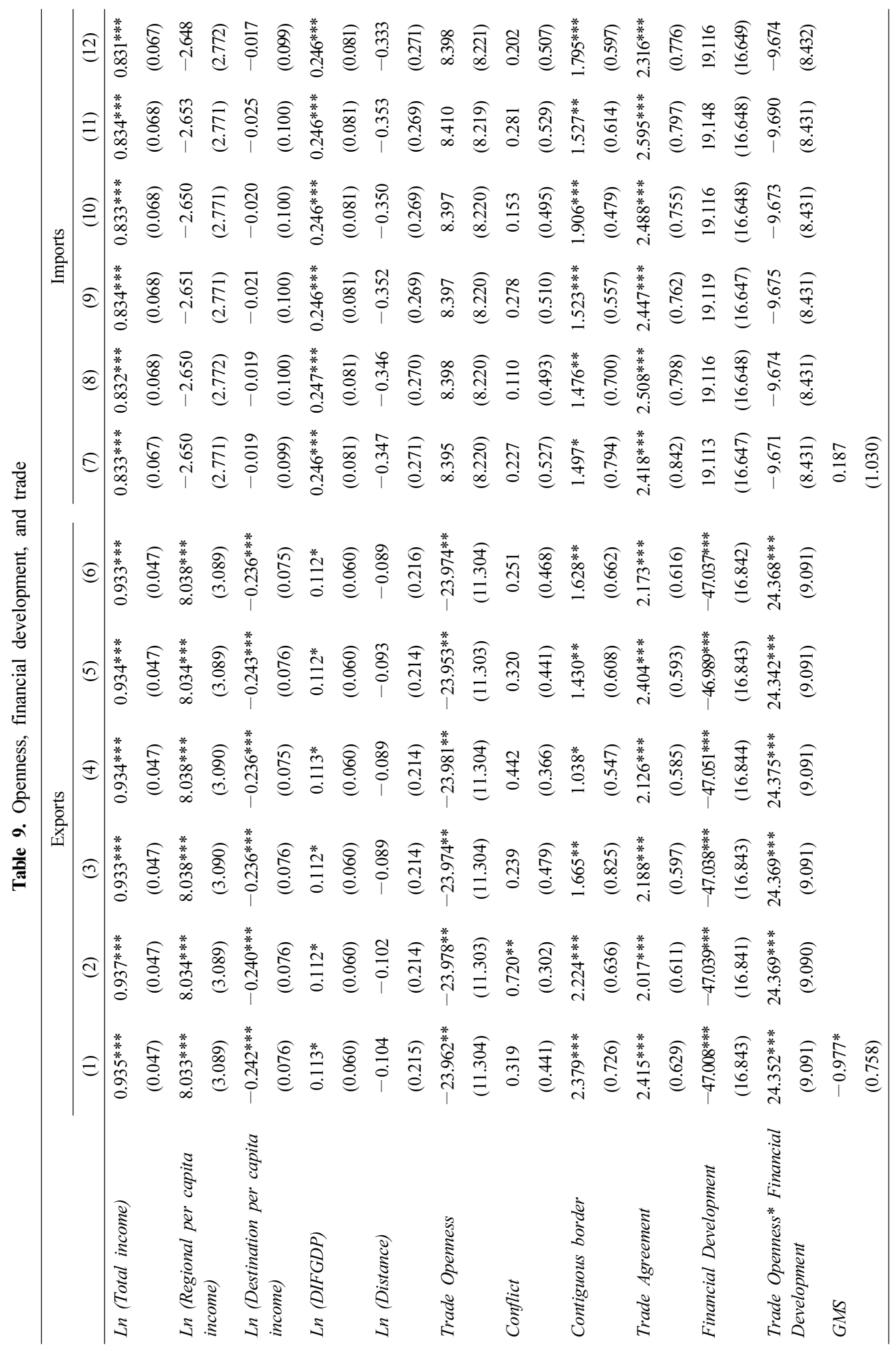




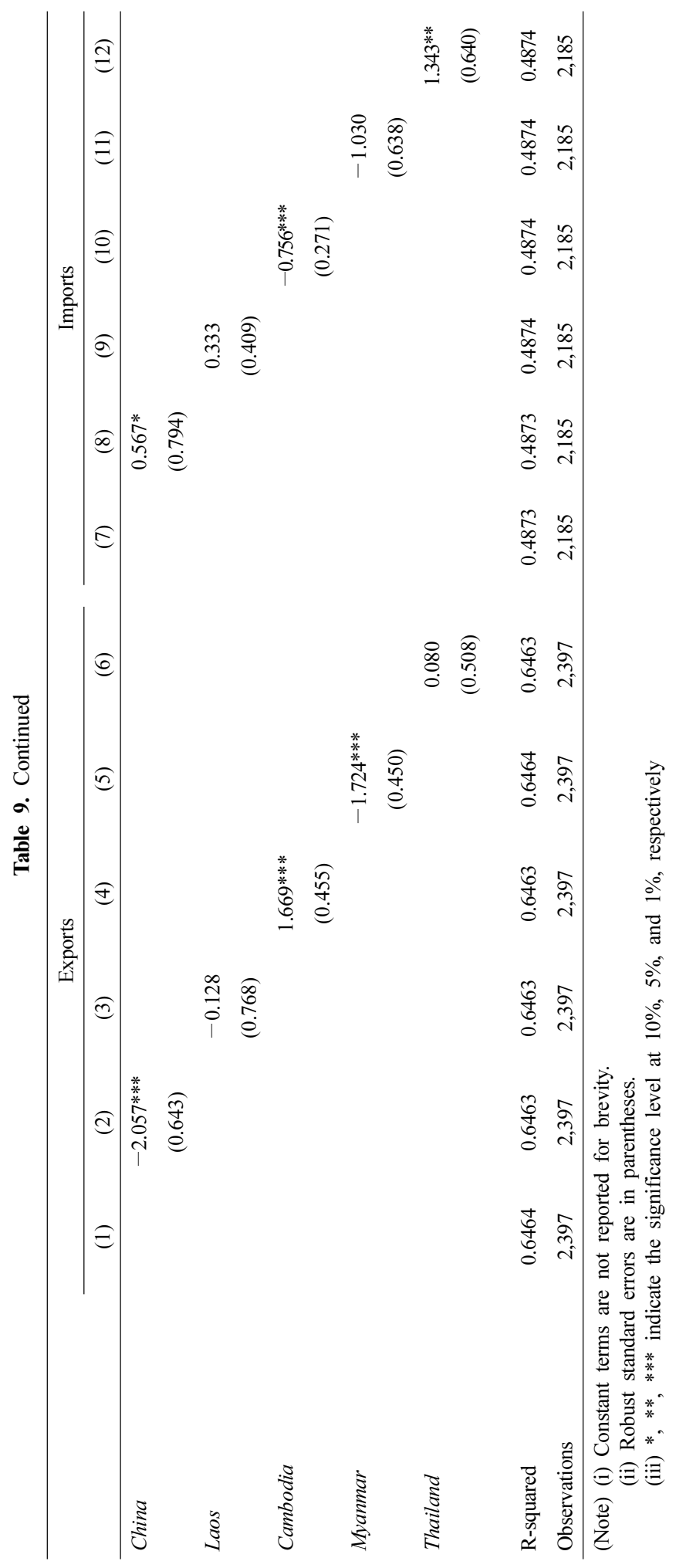


development could be an important channel that facilitates Vietnam's exports and helps reduce its reliance on imports, thus mitigating the trade deficit.

The signs of their coefficients of the other variables largely comport with our prior findings when we include Financial Development and its interaction term with Trade Openness into the Eq. (3).

\section{Conclusion and Policy Implications}

The nexus between regional economic cooperation and trade gain has been studied by many researchers. Although researchers and policy makers have investigated this nexus theoretically (Fernandez and Portes, 1998; Iyoha, 2005) and empirically (Aitken, 1973; Yang \& Gupta, 2008; Yang \& Martinez-Zarzoso, 2014), their findings have not reached a consensus.

China's recently proposed BRI has revived the debate on the effectiveness of regional cooperation. Since the impact of regional economic cooperation on trade outcomes is contingent upon country-specific features (e.g., economic size) and capacities (the level of financial development and human capital), it is vital that economists and policymakers conduct more in-depth investigations on whether and through which channels cooperation facilitates or impedes trade. Our paper responds to this need by empirically assessing the trade relations between Vietnam and its GMS partners.

Using the gravity model of trade on a large sample of Vietnam and its trading partners during the period 2000-2015, we found that regional economic cooperation in the GMS did not facilitate Vietnam's trade as expected, as evidenced by perennial trade deficits. Specifically, Vietnam's exports with GMS members are far below the level predicted by distance, relative economic size, and development. For example, we found that Vietnam's exports to China its largest trading partner - and Myanmar are much lower than the expected level, whereas the total value of Vietnam's imports from China and Thailand is above the normal level. We also found that human capital enhancement and financial development are two important channels that facilitate Vietnam's trade and help mitigate its trade deficits.

Our study recommends policies to stimulate trade flows. The empirical results may help the Vietnamese government identify the benefits and costs of participating in GMS cooperation, subsequently developing an appropriate trade strategy. In addition, we recommend that governments of small and developing countries like Vietnam should devote more effort to improving their financial systems, and invest in human capital in order to encourage domestic production, improve the quality of the labor force, and lessen their dependence on imports from other countries. 


\section{References}

Ahmed, N. (2000). Export response to trade liberalization in Bangladesh: A cointegration analysis. Applied Economics, 32(8), 1077-1084.

Aitken, N. D. (1973). The effect of the EEC and EFTA on european trade: A temporal cross-section analysis. American Economic Review, 63(5), 881-892.

Anderson, J. E., \& Van Wincoop, E. (2003). Gravity with gravitas: A solution to the border puzzle. American Economic Review, 93(1), 170-192.

Arslan, I., \& Van Wijnbergen, S. (1993). Export incentives, exchange rate policy and export growth in Turkey. The Review of Economics and Statistics, 75(1), 128-133.

Baldwin, E. R., \& Venables, J. A. (2004). Regional economic integration, London school of economics.

Baldwin, R., \& Taglioni, D. (2006). Gravity for Dummies and Dummies for Gravity Equations. NBER working paper 12516.

Beck, T. (2002). Financial development and international trade: Is there a link? Journal of International Economics, 57(1), 107-131.

Cheng, I. H., \& Wall, H. J. (2005). Controlling for heterogeneity in gravity models of trade and integration. Federal Reserve Bank of St. Louis Review, 87(1), 49-63.

Cipollina, M., \& Salvatici, L. (2010). Reciprocal trade agreements in gravity models: A meta-analysis. Review of International Economics, 18(1), 63-80.

Contractor, F., \& Mudambi, S. (2008). The influence of human capital investment on the exports of services and goods: An analysis of the top 25 services outsourcing countries. Management International Review, 48(4), 433-445.

Dosch, J., \& Hensengerth, O. (2005). Sub-regional cooperation in Southeast Asia: The Mekong Basin. European Journal of East Asian Studies, 4(2), 263-286.

Du, J., \& Zhang, Y. (2018). Does One Belt One Road initiative promote Chinese overseas direct investment? China Economic Review, 47, 189-205.

Fernandez, R., \& Portes, J. (1998). Returns to regionalism: An analysis of nontraditional gains from regional trade agreements. The World Bank Economic Review, 12(2), 197-220.

Gomez-Mejia, L. R. (1988). The role of human resources strategy in export performance: A longitudinal study. Strategic Management Journal, 9, 493-505.

Hoekman, B. M., English, P., \& Mattoo, A. (2002). Development, trade and the WTO: A handbook (English), Washington, DC: World Bank.

Kahouli, B., \& Maktouf, S. (2015). Trade creation and diversion effects in the Mediterranean area: Econometric analysis by gravity model. The Journal of International Trade \& Economic Development, 24(1), 76-104.

Kastner, S. L. (2007). When do conflicting political relations affect international trade? Journal of Conflict Resolution, 51(4), 664-688.

Kavallari, A., Maas, S., \& Schmitz, P. M. (2008). Explaining German imports of olive oil: Evidence from a gravity model. European Association of Agricultural Economists International Congress, August 26-29, 2008, Ghent, Belgium. 
Keum, K. (2010). Tourism flows and trade theory: A panel data analysis with the gravity model. The Annals of Regional Science, 44(3), 541-557.

Khazeh, K., \& Clark, D. (1990). A case study of effects of developing country integration on trade flows: The Andean Pact. Journal of Latin American Studies, 22(2), 317-330.

Krongkaew, M. (2004). The development of the Greater Mekong Subregion (GMS): Real promise or false hope? Journal of Asian Economics, 15(5), 977-998.

Krueger, A. O. (1997). Trade policy and economic development: How we learn (No. w5896). National Bureau of Economic Research.

Lee, C. C., \& Chang, C. P. (2009). FDI, financial development, and economic growth: International evidence. Journal of Applied Economics, 12(2), 249-271.

Levin, A., \& Raut, L. K. (1997). Complementarities between exports and human capital in economic growth: Evidence from the semi-industrialized countries. Economic Development \& Cultural Change, 46(1), 155.

Lewer, J. J., \& Van den Berg, H. (2008). A gravity model of immigration. Economics Letters, 99(1), 164-167.

Milton, A. I. (2005). Working Paper 77 - Enhancing Africa's trade: From marginalization to an export-led approach to development. Working Paper Series 212, African Development Bank.

Mwasha, O. N. (2008). The benefits of regional economic integration for developing countries in Africa: A case of East African community (EAC). Korea Review of International Studies, 69-92.

Narayan, S., \& Nguyen, T. T. (2016). Does the trade gravity model depend on trading partners?: Some evidence from Vietnam and her 54 trading partners. International Review of Economics \& Finance, 41, 220-237.

OECD. (2005). Analysis of non-tariff barriers of concern to developing countries. OECD Trade Policy Papers, No. 16, OECD Publishing, Paris, https://doi.org/10.1787/223281783722.

Oh, C. H., \& Selmier II, W. T. (2008). Expanding international trade beyond the RTA border: The case of ASEAN's economic diplomacy. Economics Letters, 100(3), 385-387.

Park, I., \& Park, S. (2009). Reform-creating regional trade agreements and foreign direct investment: Applications for East Asia. Pacific Economic Review, 13(5), 550-566

Pham, B. M. (1999). ASEAN's economic integration opportunities and challenges for Vietnam. Weatherhead Center for International Affairs.

Poncet, S. (2006). Economic integration of Yunnan with the Greater Mekong Subregion. Asian Economic Journal, 20(3), 303-317.

Prehn, S., Brümmer, B., \& Glauben, T. (2016). Gravity model estimation: fixed effects vs. random intercept Poisson pseudo-maximum likelihood. Applied Economics Letters, 23(11), 761-764.

Rajan, R., \& Zingales, L. (1998). Financial development and growth. American Economic Review, 88(3), 559-586

Salvatore, D. (2006). International Economics, 8th Ed, Willey International Edition, USA.

Schmidt, U. (2004). Vietnam's integration into the global economy: Achievements and challenges. Asia Europe Journal, 2(1), 63-83.

Shahbaz, M., \& Mafizur Rahman, M. (2014). Exports, financial development and economic growth in Pakistan. International Journal of Development Issues, 13(2), 155-170.

Svaleryd, H., \& Vlachos, J. (2005). Financial markets, the pattern of industrial specialization and comparative advantage: Evidence from OECD countries. European Economic Review, 49(1), 113-144.

Tinbergen. (1962). Shaping the world economy: Suggestions for an international economic policy, New 
York: The Twenty Century Fund.

Todaro, M. P., \& Smith, S. C. (2015). Economic Development. 12th Ed. Boston: Pearson Addison Wesley. Vannarith, C. (2018a). Understanding China's regional economic diplomacy through LMC and BRI. Mediu m, 31 July. Available at https://medium.com/@lseseac/understanding-chinas-regional-economic-diplo macy-through-lmc-and-bri-c804640df460 [Accessed 12 March 2019].

Vannarith, C. (2018b). China's economic statecraft in Southeast Asia. ISEAS Perspective, No 45, Issue 2018. Singapore: ISEAS-Yusof Ishak Institute.

World Trade Organization (2013). Trade policy review on Vietnam. [pdf] Geneva: World Trade Organization. Available at https://www.wto.org/english/tratop_e/tpr_e/tp387_e.htm [Accessed 10 June 2019].

Yang, S., \& Martinez-Zarzoso, I. (2014). A panel data analysis of trade creation and trade diversion effects: The case of ASEAN-China Free Trade Area. China Economic Review, 29, 138-151.

Yang, Y., \& Gupta, S. (2008). Regional trade arrangements in Africa: past performance and the way forward. African Development Review, 19(3).

Yu, X. (2003). Regional cooperation and energy development in the Greater Mekong Sub-region. Energy Policy, 31(12), 1221-1234.

Yu, Y., \& Chang, Y. (2018). The 'One Belt One Road' Initiative and its impact on shipping law in China. Marine Policy, 87, 291-294.

Zhai, F. (2018). China's belt and road initiative: A preliminary quantitative assessment. Journal of Asian Economics, 55, 84-92. 